\title{
PERENCANAAN PUSAT EDUKASI DAN TERAPI AUTIS DI KOTA PEKANBARU RIAU
}

\author{
Syafitri Melinda,Rika Cheris,Repi Repi \\ Program Studi Arsitektur, Fakultas Teknik, Universitas Lancang Kuning \\ Jl. Yos Sudarso km. 8 Rumbai, Pekanbaru, Telp. (0761) 52324 \\ Email: fitrimelinda1@yahoo.com
}

\begin{abstract}
ABSTRAK
Prediksi penyandang autis di Indonesia dari tahun ke tahun semakin meningkat. Sepuluh tahun yang lalu jumlah penyandang autis diperkirakan satu per 5.000 anak, Tahun 2015 di perkirakan terdapat sebanyak kurang lebih 12.800 anak penyandang autis atau 134.000 penyandang spektrum Autis di Indonesia. Autis adalah suatu kondisi mengenai seseorang sejak lahir atau pun saat masa balita, yang membuat dirinya tidak dapat membentuk hubungan sosial atau komunikasi yang normal. Sehingga dalam mendisain pusat edukasi dan terapi autis memelukan konsep pendekatan arsitektur perilaku untuk kenyamanan dari penyandang autis, yang mana perilaku berasal dari kata laku yang berarti perbuatan, kelakuan, cara menjalankan atau berbuat. Dengan menggunakan metode penelitian tengumpulan data, analisa pemakai bangunan, analisa bangunan dan analisa lingkungan yang mana akan menghasilkan konsep bangunan pusat edukasi dan terapi autis dengan pendekatan arsitektur perilaku.
\end{abstract}

Kata Kunci : Konsep, Penyandang Autis, Terapi,Arsitektur Perilaku, Pusat Edukasi.

\section{ABSTRACK}

Predictions of autistic people in Indonesia from year to year are increasing. Ten years ago the number of people with autism was estimated at one per 5,000 children, in 2015 it was estimated that there were approximately 12,800 children with autism or 134,000 people with autism spectrum in Indonesia. Autism is a condition regarding a person from birth or even during infancy, which makes him unable to form a normal social or communication relationship. So that in designing education centers and autism therapy requires the concept of behavioral architectural approaches to the comfort of people with autism, which behavior comes from the behavior that means action, behavior, way of doing or acting. By using research methods data collection, building user analysis, building analysis and environmental analysis which will produce the concept of building education centers and autistic therapy with a behavioral architecture approach.

Keywords: Concept, Autistic Person, Therapy, Behavioral Architecture, Education Center.

\section{PENDAhuluan}

Perkembangan jumlah penduduk Pekanbaru terjadi peningkatan pada tahun 2016 yang berjumlah 1.046566 jiwa, terdiri dari 546.400 jiwa penduduk laki-laki dan 518.166 jiwa penduduk perempuan.( riaubps)

Dari jumlah penduduk tersebut terdapat penyandang autis namun belum terdata seluruhnya. Berdasarkan pendataan yang dilakukan Forum Pengembangan Anak Penyandang Autis (F-PAPA Riau) pada akhir Maret 2013 terhadap 9 Sekolah Luar Biasa, 4 Sekolah Inklusi dan 7 Klinik Terapi di Pekanbaru terdapat ada 250 anak autis yang menjadi siswanya.(riaupos)

Prediksi penyandang autis di Indonesia dari tahun ke tahun semakin meningkat. Sepuluh tahun yang lalu jumlah penyandang autis diperkirakan satu per 5.000 anak, Tahun 2015 diperkirakan terdapat kurang lebih 12.800 anak penyandang autis atau 134.000 penyandang spektrum Autis di Indonesia. Jumlah tersebut setiap tahun terus meningkat. Hal ini sungguh patut di waspadai karena jika penduduk di Indonesia saat ini mencapai lebih dari 160 juta, kira-kira berapa orang yang dicurigai mengalami gangguan spektrum autis.(KLINIKAUTISonline)

Dengan adanya peninggkatan penyandang autis di Riau, khususnya kota Pekanbaru perlunya tempat yang mampu menampung penyandang autis walau pun sudah terdapat sekolah khusus autis namun perlunya banyak fasilitas penunjang untuk anak autis belum memadai di sekolah. Untuk itu perlu adanya sebuah pusat yang dikhususkan untuk anak autis bersosialisasi dan fasilitas terapi .Salah satu upaya yang tepat adalah dengan merancang sebuah pusat edukasi dan terapi anak autis agar penyandang autis dapat terrealisasi secara berkelanjutan dengan baik. 


\section{METODE PENELITIAN}

Untuk mendapatkan hasil yang maksimal memerlukan metode penelitian adalah pengumpulan data-data yang terkait dengan perencanaan dan perancangan antara lain :

\subsection{Pengumpulan data}

Pengumpulan data baik dari surve lapangan,studi banding, reverensi dari buku maupun jurnal, cara data primer dan pencarian data secara sekunder.

\subsection{Tahap Analisa}

Data yang di dapat akan dianalisa untuk mencari solusi terhadap perencanaan. Tahap analisa dapat dilakukan dengan dua tahap antara lain tahap analisa secara makro dan tahap analisa secara mikro

\subsection{Tahap Penyusun Konsep}

Tahap penyusunan konsep perancanaan yang akan di gunakan untuk membuat perancangan.

\section{HASIL PEMBAHASAN}

Beberapa tahun ini autis terjadi peningkatan yang sangat pesat, penyandang autis dapat diaknosa pada usia 18 bualan sampai 5 tahun sudah mendapatkan gejala dari autis namun bukan hanya itu edukasi dan terapi juga perlu bagi penyandang autis untuk memulihkan rasa kepercaya dirian sikap sosial yang terhambat akibat fungsi susunan syaraf pusat terganggu. Autis adalah suatu kondisi mengenai seseorang sejak lahir atau pun saat masa balita, yang membuat dirinya tidak dapat membentuk hubungan sosial atau komunikasi yang normal. Autis bukanlah penyakit kejiwaan karena ia merupakan suatu gangguan yang terjadi pada otak sehingga menyebabkan otak tersebut tidak dapat berfungsi selayaknya otak normal dan hal ini termanifestasi pada perilaku penyandang autis. Autis adalah yang terberat di antara (jurnal lpediatri,2011.)

Penyebab dari autis belum di ketahui secara pasti namun ada sebuah penelitian terdapat beberapa faktor penyebab autis adalah karna ada gangguan pada susunan saraf pusat yang gaguan fungsi ini mengakibatkan kelainan struktur otak yang biasanya terjadi pada usia kandungan di bawah 3 bulan. Ibu si janin mungkin sedang mengidap virus TORCH (tokso. rubella, cytomegali, herpes), memakan makanan yang banyak mengandung zat kimia menggangu pertumbuhan sel otak terhadap janin, menghirup udara beracu, pendarahan hebat, buakan hanya itu faktor ginetik juga berperan penting memicunya autis.(rahayu,2014)
Sehingga dalam mendisain pusat edukasi dan terapi autis memelukan konsep pendekatan arsitektur perilaku untuk kenyamanan dari penyandang autis, yang mana perilaku berasal dari kata laku yang berarti perbuatan, kelakuan, cara menjalankan atau berbuat. Jadi perilaku merupakan perbuatan, tanggapan individu atau reaksi yang dikenakan kepada, atau terhadap segala sesuatu yang terwujud dalam gerakan tubuh (sikap) tidak saja badan atau ucapan. perilaku yang mana beberapa pendekatan arsitektur prilaku menurut (Setiawan. B, Haryadi.)Antara lain :

- $\quad$ Ruang

- Bentuk dan Ukuran

- Perabot dan Penataannya

- Warna Ruang

- Suara, Suhu Udara dan pencahayaan

Dari pendekatan prilaku penyandang autis menjadi acuan paling utama di dalam bangunan ini, perilaku yang menbuat standar kebutuhan ruang dalam bangunan pusat edukasi dan terapi autis.( (hariadi) Dengan menggunakan metode analisa yang telah di tetap kan antara lain :

\subsection{Aspek Pemakai Banguanan}

Untuk Pusat edukasi dan terapi autis ini terdapat 3 pelaku yang melakukan aktivitas didalamnya, yaitu :

1. Pengelola

Untuk menghasilkan tempat eduukasi dan terapi yang baik maka masing-seluruh pengelola yang bekerja harus memiliki sifat:

- Sabar

- Komunikasi dengan baik

- Dapat memahami penandang autis

Dari hasil tersebut menghasilkan pemakai bangunan yang masing-masing pengelola memiliki aktivitas :

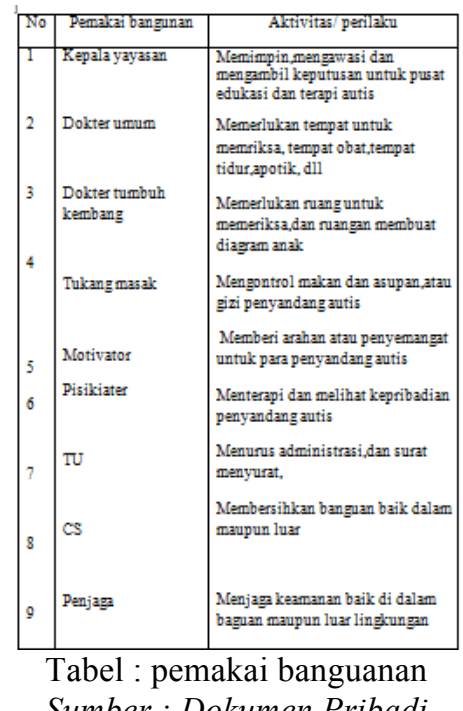

Sumber : Dokumen Pribadi 
2. Penyandang autis

Penyandang autis memiliki prilaku-prilaku yang sebaiknya di dukung oleh ruangan agar tidak menyakiti atau mengganggu aktifitas penyandang autis tersebut, berikut perilaku dan kebutuhan ruangannya:

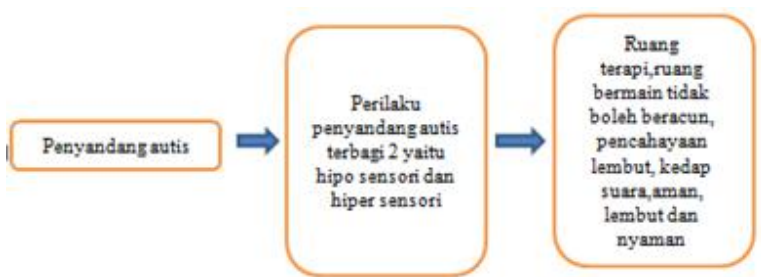

Skema : Perilaku Penyandang Autis Sumber : Dokumen Pribadi

Maka penyandang autis memerlukan jenis terapi dan aktivitas :

\begin{tabular}{|c|c|c|}
\hline No & Terapi & Aktivitas \\
\hline 1 & Terapi prilaku & $\begin{array}{l}\text { Untuk mengarahkan prilaku } \\
\text { penyandang autis sesuai dengan } \\
\text { printah }\end{array}$ \\
\hline 2 & Terapi okupas & Untuk melatih otot-otot pada tubuh \\
\hline 3 & Terapi wicara & Untuk melatih otot pada mulut \\
\hline 4 & Terapi biomedis & $\begin{array}{l}\text { Pada terapi ini difokuskan pada } \\
\text { pembersihan fungsi-fungsi } \\
\text { abnormal pada otak dan obat-o }\end{array}$ \\
\hline 6 & Terapi bermain & $\begin{array}{l}\text { kebebasan eksplorasi dan ekspresi } \\
\text { diri }\end{array}$ \\
\hline
\end{tabular}

Tabel : terapi penyandang autis Sumber : Dokumen Pribadi

3. Pegunjung atau orang tua

Pengunjung atau orang tua merupakan bagian pemakai ang tidak selalu berada di bangunan tersebut sehingga fasilitas yang di butuhkan :

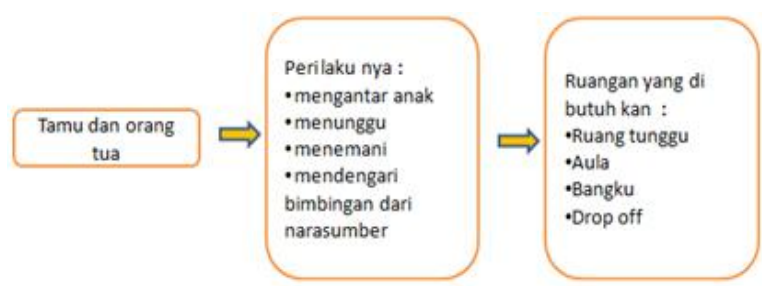

Skema : perilaku pemakai bangunan Sumber : Dokumen Pribadi

Maka dari analisa perilaku dari pemakai bangunan sehingga di perlukan ruang-ruang yang lebih fungsional terhadap pemakai banagunan.

\subsection{Analisa Besaran Ruang}

\begin{tabular}{|c|l|r|}
\hline \multicolumn{3}{|c|}{ REKAPITULASI } \\
\hline No & \multicolumn{1}{|c|}{ Nama Fasilitas } & \multicolumn{1}{c|}{ Luas } \\
\hline 2 & FASILITAS PENGELOLAH & 805.3 \\
4 & FASILITAS TRAPI AUTIS & 4887 \\
8 & FASILITAS PENUNJANG & 815.4 \\
9 & FASILITAS SERVICE & 150 \\
10 & FASILITAS PARKIR & 866.4 \\
\hline \multicolumn{3}{|c|}{ TOTAL LUAS BANGUNAN } \\
\hline
\end{tabular}

Tabel : Besaran Ruang Sumber : Dokumen Pribadi

\subsection{Analisa Arsitektur}

Analisa arsitektur ruang pada bangunan yang mengikuti tema yaitu arsitektur perilaku yang mana beberapa pendekatan arsitektur prilaku menurut (Setiawan. B, Haryadi.)Antara lain :

- Ruang

- Bentuk dan Ukuran

- Perabot dan Penataannya

- Warna Ruang

- Suara, Suhu Udara dan pencahayaan

Analisa bentuk bangunan Untuk penentuan bentuk dari dasar bangunan harus memperhatikan

a. Bentuk dari perilaku penyandang autis yang sesuai dengan tema yaitu arsitektur perilaku

b. Menyesuaikan arah orientasi matahari

c. Pertimbangan terhadap titik tangkap dan kesan pengguna

\subsection{Analisa Aspek Lokasi Dan Site}

Lokasi yang terpilih Lokasi terpilih yang akan digunakan dalam perencanaan pusat edukasi dan terapi autis yaitu berada diperovinsi Riau,kota Pekanbaru di wilayah WP IV yang terletak di Jl. Segar kecamatan Tenayan Jaya Keadaan tapak kondisi tapak yang terpilih pilih 


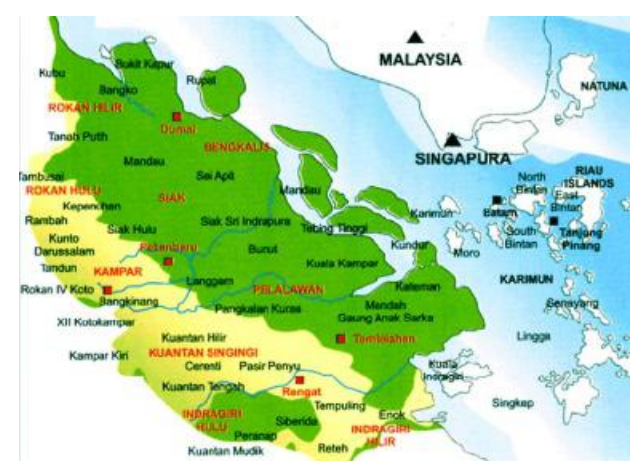

Gambar : peta provinsi riau Sumber : Internet 2017/2018

Data Tapak dari analisa yang dilakukan untuk pemilihan site pusat edukasi dan terapi autis maka terpilih lah site yang berada di Kecamatan Tenayan jaya, Kota Pekanbaru Provinsi Riau dengan Luas Tapak $8000 \mathrm{~m}^{2}$. Yang batas Utara PDTA nurul islam, Batas Timur balai riset dan standarisasi industry,Batas Selatan : lahan kosong, Batas Barat : rumah warga

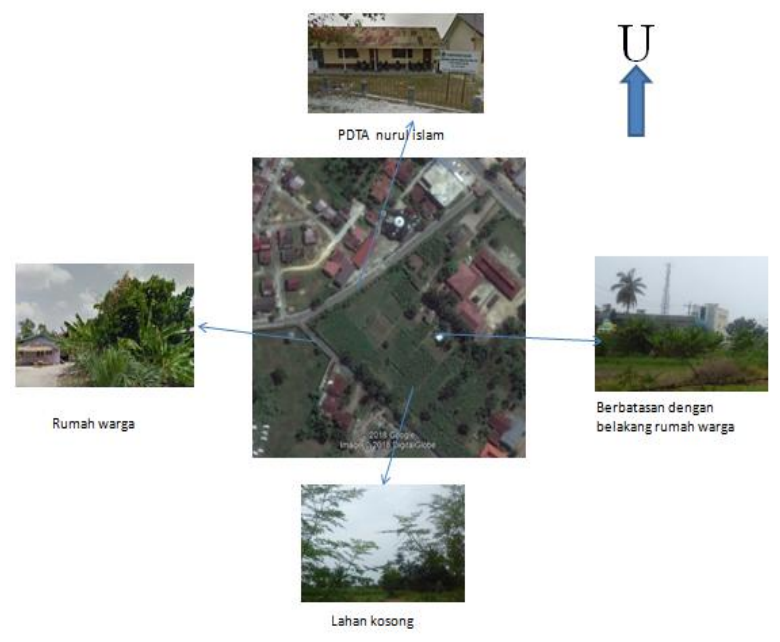

Gambar : Batas Site

Sumber : Surve Lapangan

\subsection{Konsep Dasar Perancangan}

Penggunaan konsep dasar perancangan dengan pendekatan yang dilandaskan sesuai topik yaitu aritektur perilaku dan tema perancangan arsitektur terhadap lingkungan dan perilaku di dalam bangunan pusat edukasi dan terapi autis, sehingga perancangan arsitektur terhadap lingkungan dan perilaku sebagai arah untuk membentuk bangunan yang mampu memberikan kenyamanan keindahan dan pemulihan bagi pengguna bangunan terutama penyandang autis.(marzuki,2013)

\subsection{Konsep Bentuk Masa Bangunan}

Masa bangunan membantu tahapan kemandirian dari penyandang autis dan kenyamanan yang mana penyandang autis memiliki sifat hiper aktif sehingga faktor keamanan, efisien dan dinamis menjadi pertimbangan.

1. Bentuk dari segi empat sangat baik untuk di olah pada bangunan karena segi empat cukup fungsional dan efesien pada bangunan

2. Sementara bentuk lingkaran sangat sedikit sulit diaplikasikan dan kurang fungsional dari bentuk tersebuat tapi bagi penyandang autis sangat baik karna lingkaran meminimalisir sudut karana penyandang autis menghidari sudut. Dalam menentukan konsep secara menyeluruh adanya wujud arsitektur fungsional yang di rangkai dalam lingkungan binaan.

Pusat edukasi dan terapi autis merupakan bagian yang bersifat pendidikan yang mana penekanannya pada kenyamanan dan keamanan terhadap pemakai bangunan.

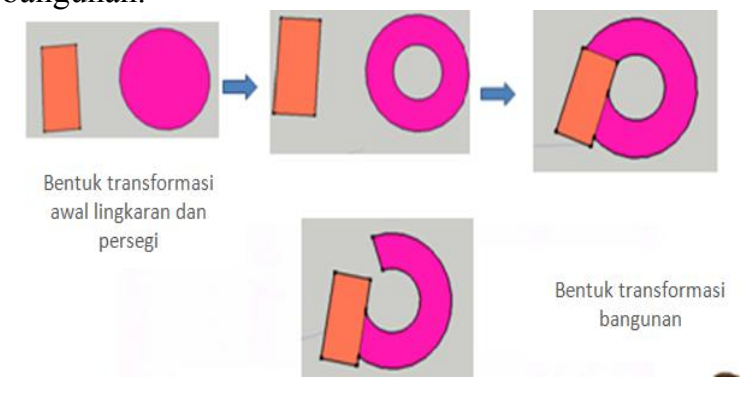

Gambar : dasar bentuk

Sumber : Dokumen Pribadi

\subsection{Konsep Penataan Ruang Dan Masa Pada Banguana}

1. Konsep pola sirkulasi ruang dan hubungan ruang

Persegi sebagai penyambut dan untuk bangunan trapi dibuat melinkar yang mana lingkaran sangat baik untuk penyandang autis karna meminimalisir sudut dan taman tematik di tengah bangunan untuk memudahkan pengawasan dan lebih memuasat,taman tersebut selain itu fungsi dari taman untuk merangsang visual dari penyandang autis.

2. Hubungan bangunan

Hubungan masa pada bangunan menggunakan koridor atau ruangan yang membentuk linear yang membentuk polapola pada dinding agar penyandang autis tidak merasa jenuh dan perilaku penyandang autis yang suka meraba sekalian sebagai terapi peraba, mudahkan sirkulasi perjalanan bagi pemakai bangunan. 


\subsection{Konsep Zoning}

Konsep perletakan masa di tentukan dari hasil analisa site yaitu analisa pencapaian, analisa sirkulasi. Dan untuk masa bangunan mempetrimbangkan dari hasil analisa orientasi matahari dan pemakai bangunan tersebut, sehingga dapat meminimalkan penggunaan energi pada bangunan dan memenafaatkan sebaik-baik mungkin.

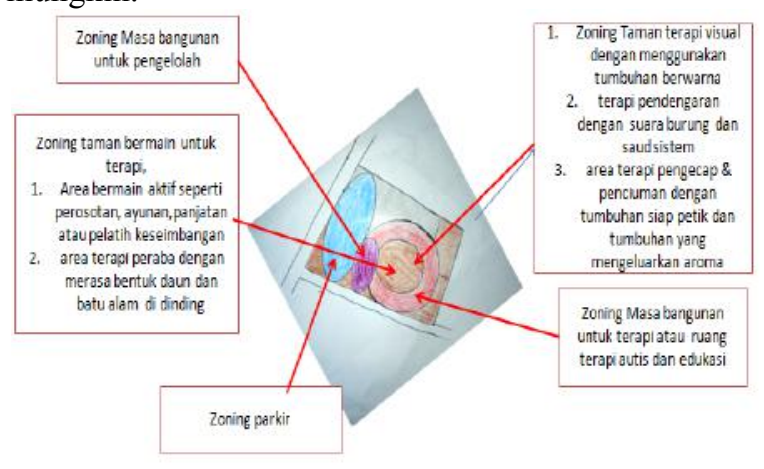

Gambar : Konsep Zoning

Sumber : Dokumen Pribadi

- Perletakan area parkir di bagian depan mempertimbangkan kebisingan yang tinggi pada bagian depan site

- Bangunan pengelola dijadikan sebagai penyambut pengguna bangunan maupun fasilitas bangunan

- Taman di letakkan dibagian tengah bangunan merupakan salah satu terapi bagi penyandang autis, area bermain dan pusat kegiatan untuk penyandang autis untuk saling bersosialisasi yang langsung diawasi orang tua yang sedang menunggu dan memudah kan dalam pengawasan

- Ruang edukasi dan terapi di buat melinkar karena pertibangan dari sifat dari penyandang autis yang mana menghidari sudutsudut,memudahkan dalam pengawasan terhadap si penyandang autis dan para penyandang autis sangatlah peka terhadap keributan

\subsection{Konsep Landscape}

Penanaman pohon atau tumbuhan pada banggunan dapat membantu terapi visual, keaktifan, penciuman dan pengecap, pendengaran peraba.

1. Terapi visual dengan menanam tanaman hiasan yang berwarna warni

2. Terapi keaktifan dangan mewujudkan tempat bermain seperti prosotan, ayunan, panjatan atau pelatih keseimbangan

3. Terapi penciuman dan pengecap dengan menggunakan tumbuhan siap petik penciuman dengan tumbuhan seperti mawar,melati lavender dan lain-lain

4. Terapi pendengaran dengan menyiapkan suara hewan seperti burung dapat menbantu anak lebih aktif dan keingintahuan

5. Terapi peraba lebih kebentuk tekstur dinding

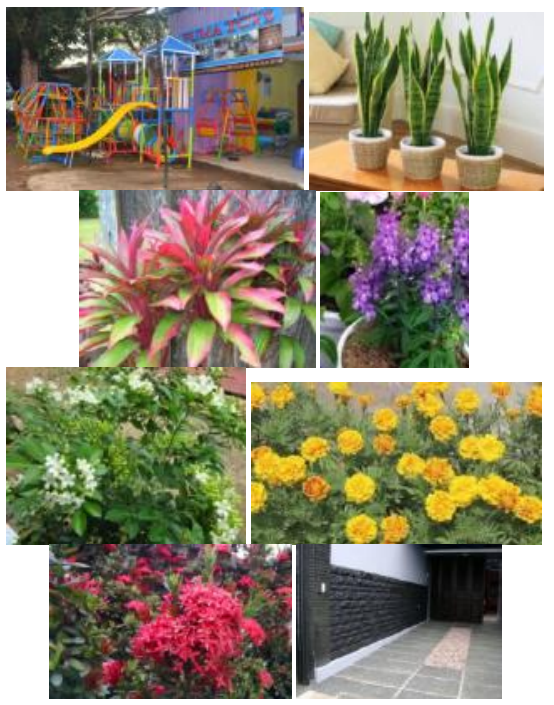

Gambar : tanaman untuk lanscap

Sumber : Internet 2017/2018

\subsection{Konsep Ruang Terapi}

Anak penyandang autis terbagi dua perilaku yaitu hipo sensori yang mana keterlambatan menerima respon sekitarnya sehingga emosi yang di timbulkan yaitu sering melamun, tertawa, menangis tanpa sebab, sementara hiper sensori terlaku peka terhadap lingkungan sekitar sehingga tingkah lakunya lebih hiperaktif, suka menjeritan memukul tanpa sebab.( (gaista 2016)

1. Konsep Pengahawaan

Penghawaan alami pada banguanan baik utuk kesehatan penyandang autis dengan meletakkan jendela untuk sirkulasi silang, namun untuk ruang terapi perletakan jendela juga diperhatikan agar anak anak saat terapi tidak melihat keluar.

Penghawaan buatan dengan menggunakan AC (air conditioner) split pada ruang-ruang perkantoran, ruang detoksifikasi, ruang medis dan exhaust fan.

2. Konsep Pencahayaan

Pencahayaan alami sangatdi butuhkan bagi kesehatan penyandang autis, Untuk 
penerangan menggunakan jendela yang konsep cahaya pencahayaan merata, tidak langsung, untuk ruangan terapi lampu berwarna cool white dan lampu ceiling sementara untuk ruang hiper pencahayaan alami langsung pencahayaan buatan langsung secara tidak merata, lampu berwarna kuning (cool yellow) dan menyorot.(gaista 2016)
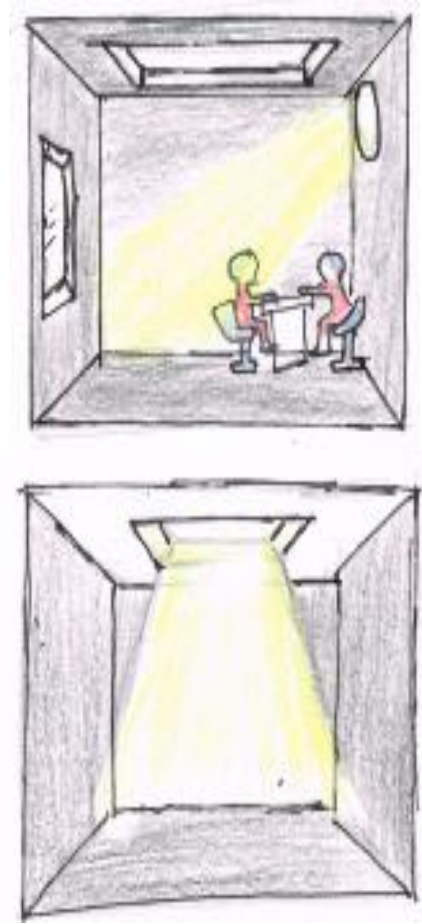

Gambar: pencahayaan ruangan Sumber : Dokumen Pribadi

\section{Konsep Warna}

Warna yang digunakan pada area terapi adalah mengikuti tipe dari penyandang autis yang mana ada dua tipe penyandang autis pertama adalah pada ruang terapi hiper, warna

yang diambil membentuk lebih lembut yang berkesan lebih teduh mengingat dari penyandang autis yang berprilaku hiper agar bisa lebih sejuk dan tengan. Untuk menghindari efek silau dari warna terang sedangkan anak hipo pemilihan warnanya lebih terang agar bisa meningkat semangat

bagi penyandang autis yang hipo lebih banyak diam teruntuk ruang dikarenakan memiliki warna kontras yang imbang (dingin panas).(sriti)

4. Konsep Fornitur

Pada ruang untuk trapi di bagi menjadi dua yaitu individual dan kelompok yang mana bagian kelompok ada dua tipe ruang yang

pertama kelas mandiri, susunan meja dan kursinya dibuat setengah lingkaran agar bisa

lebih fokus dan dan memudahkan pengawasan bagi pengajar, bangku dan kursi buat lebih sendiri-sendiri agar lebih mandiri menimbang penyandang autis memiliki rasa penasaran yang tinggi dan agar tidak mengganggu temannya.tipe kedua yaitu ruang trapi kelompok transisi yang mana penyandang autis di ruangan ini sudah pernah mendapatkan pendidikan sebelumnya untuk meja dan kursi dibuat setengah linkaran dan bersatu agar bisa berinteraksi sosial dangan baik dalam pengawasan.

Sementara untuk ruang terapi wicara, perilaku, okupas lebih individual didalam ruangan hanya penerapis,asisten terapis dan penyandang autis agar lebih fokus, meja dan kursi pun diletak bagian sudut agar lebih fokus, dan kedap suara karna panyandang autis suslit sekali untuk fokus
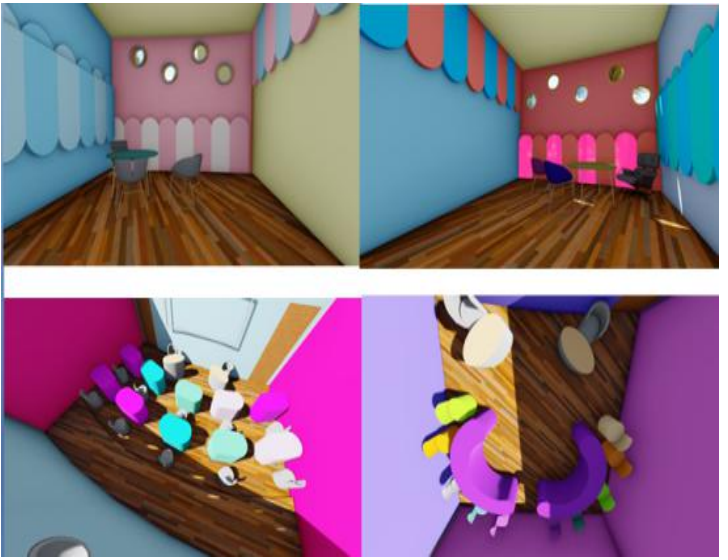

Gambar: kosep ruang kelompok dan invidual Sumber : Dokumen Pribadi 


\subsection{1. . Hasil Perancangan}

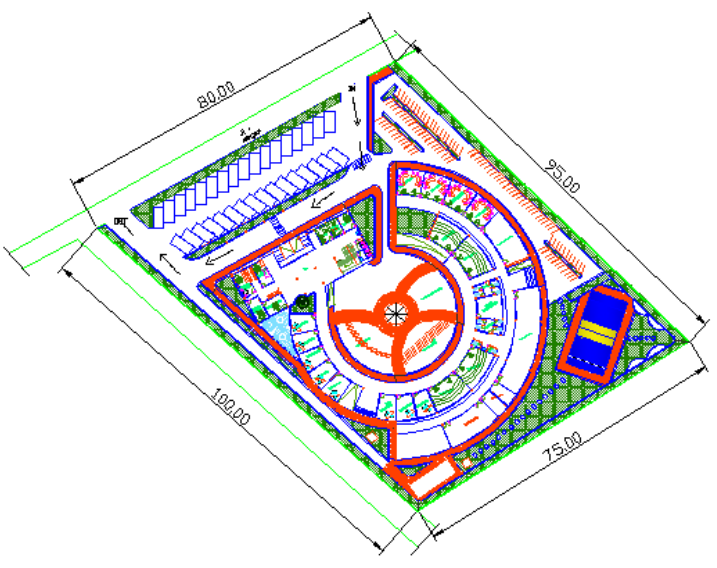

Gambar : site plan

Sumber : Dokumen Pribadi

Site plen, parkir mobil diletak kan di bagian depan untuk mengurangi sumber bunyi terbesar, dan di bagian kanan dari bangunan parkir motor. Bangunan penyambut adalah bangunan pengelolah menimbang penyandang autis sangatlah peka terhadap punyi dan gerak maka di letakkan ruang terapi di bagian belakang bangunan.sirkulasi yang dibuat di bangunan pun secara linear karna menimbang penyandang autis yang sangat sulit mengingat,ditenah bangunan merupakan terapi landscape bagi penandang autis. Di bagian belakang terdapat lapangan dan gazebo untuk terapi gerak yang dapt di awasi langsung oleh orang tua,

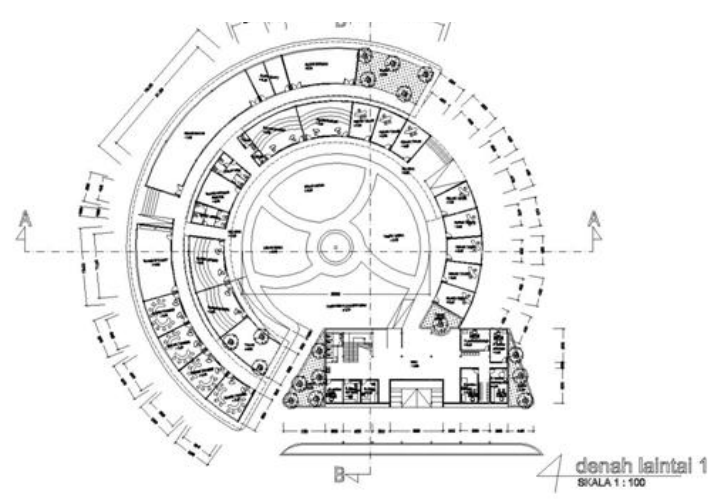

Gambar : denah lantai 1

Sumber : Dokumen Pribadi

Bentuk lingkaran diambil dari prilaku penyandang autis dimana suatu bentuk lingkaran tersebut mengurangi sudut sudut dinding yang membahayakan pengguna

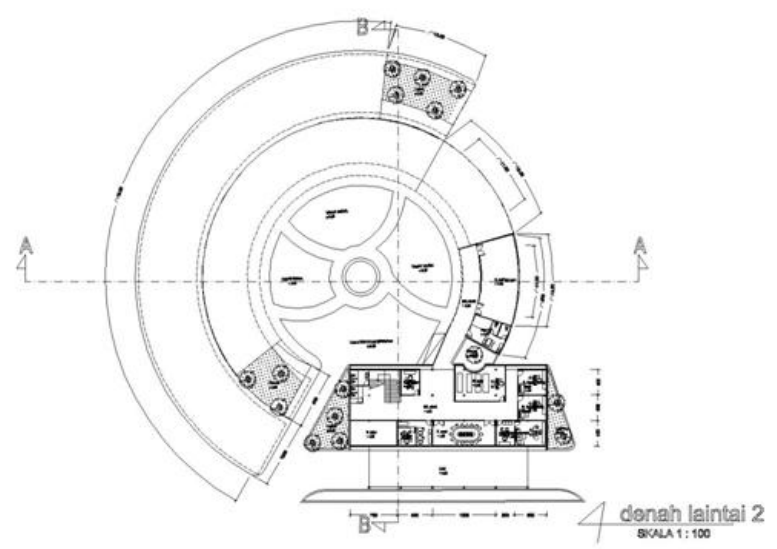

Gambar : denah lantai 2 Sumber : Dokumen Pribadi

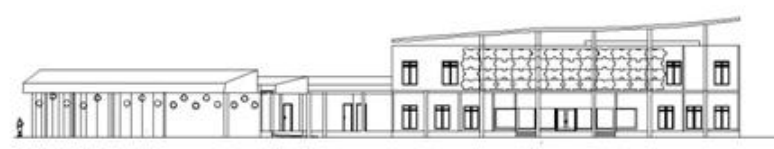

Tampak Depan

Gambar : tampak depan

Sumber : Dokumen Pribadi

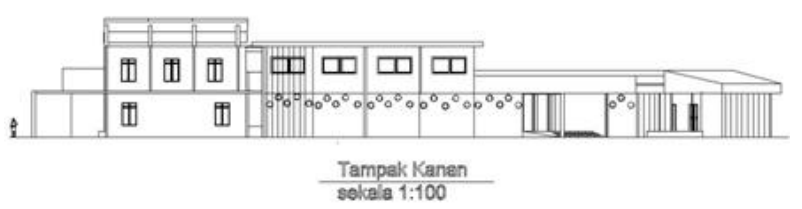

Gambar: tampak kanan

Sumber : Dokumen Pribadi

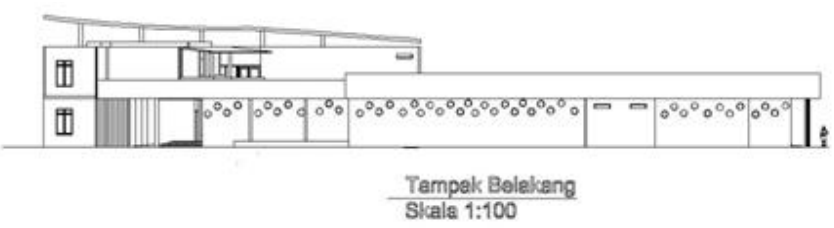

Gambar : tampak belakang

Sumber : Dokumen Pribadi

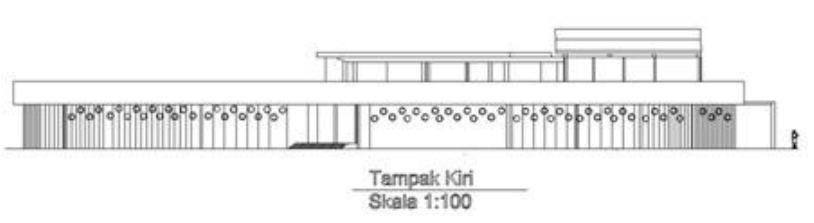

Gambar : tampak kiri

Sumber : Dokumen Pribadi 

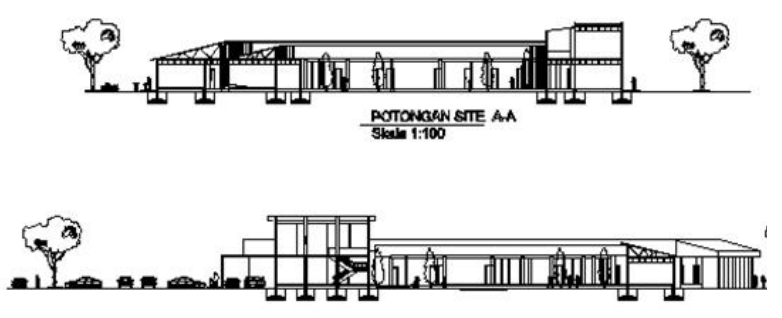

POTONaAN amE B-B

Gambar : potongan site plan

Sumber : Dokumen Pribadi

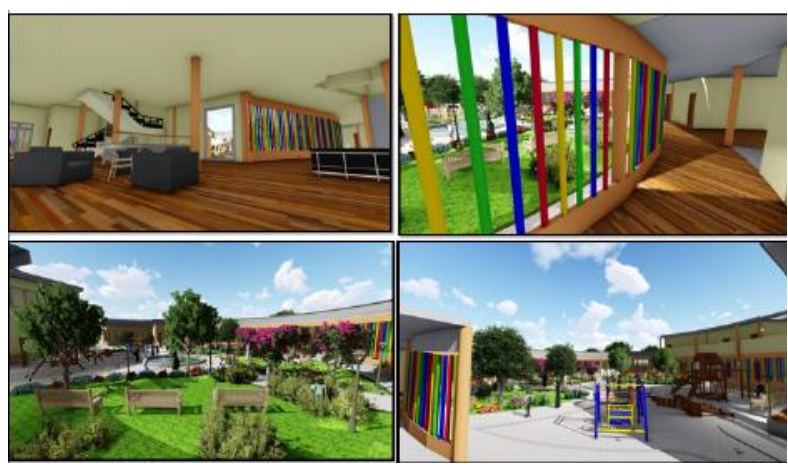

Gambar : interior dan lanscap

Sumber : Dokumen Pribadi

Interior lobi yang di disain nyaman bagi pengunjung atau orang tua saat menunggu penyandang autis terapi, dan nyaman bagi penyandang autis agar tidak lebih tertekan saat hendak terapi.

Dinding koridor di beri jerajak warna warni untuk menterapis bagi penyandang autis selain untuk membatasi ruang dalam dan ruang luar bangunan,selain itu permainan cahaya dari sela-sela bisa membantu terapi bagi penyandang autis.

Dari koridor dapat melihat keluar bangunan,dan taman gerak juga dibuat senyaman mungkin.

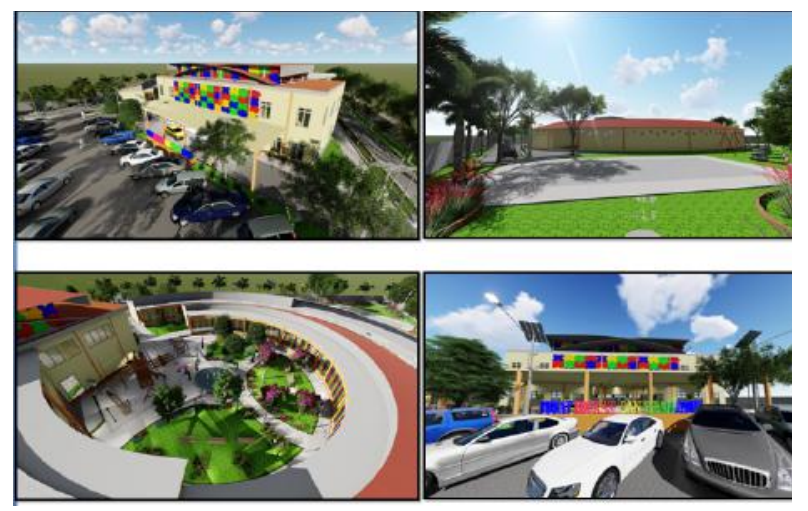

Gambar : dari luar bangunan

Sumber : Dokumen Pribadi
Bentuk linkaran dibuat sesuai dari perilaku penyandang autis yang salah satu nya menghindari sudut, selain itu juga memudahkan tenaga penerapis untuk mengawasnya karna lingkaran itu lebih memusat.

Parkir di bagian depan selain menghindari sumber kebisingan terbesar,juga memudahkan pemakai bangunan untuk mengetahui letaknya. Lapangan untuk terapi gerak penyandang autis,
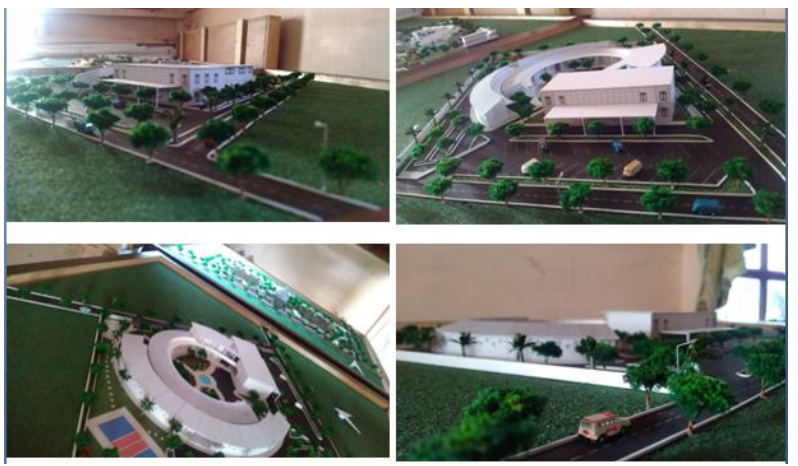

Gambar : sirkulasi banguan

Sumber : Dokumen Pribadi

Sikuasi dari luar bangunan hanya bisa melalui jalan segar yang mana keadaan jalan segar cukup ramai, sementara di dalam bangunan memakai dua jalur berbeda saaat masuk dan keluar untuk menghindari cros saat keluar dari bangunan

\section{KESIMPULAN DAN SARAN}

Desain dalam ruang dan luar bangunan nyaman dan aman salah satu upaya membuat penyandang autis merasa baik, dan setiap ruangan dibuat merangsang anak autis atau terapi seperti koridor, lobby dan lain-lain, mengingat penyandang autis memiliki perilaku yang susah ditebak bukan hanya para penyandang autis namun pemakai bangunan lain nya juga merasa nyaman.

Peran pemerintah sangatlah berpengaruh pada penanganan anak-anak berkebutuhan khusus, karna jika pemerintah memperhatikan para anakanak berkebutuhan khusus pasti masyarakat akan merasa sangat terbantu. Karna biaya dari anak berkebutuhan khusus sangatlah tinggi. 


\section{DAFTAR PUSTAKA}

B.stetiawan ,hariayadi, arsitektur lingkungan dan perilaku, jogja karata, universitas gajah mada

Neufert, Ernest. 1936, Data arsitektur, erlangga, jakarta,

Boedhi laksono, 2014, Metoda arsitektur perencanaan arsitektur,jakarta, gria swadaya grup,

James C Snyder,1991, Pengantar arsitektur, jakarta, Erlangga.

Mayang, sriti, konsep desain partisipasi dalam desin interior ruang terapi perilaku anak autis, jurnal disain interior, Surabaya

Muji rahayu, sri, deteksi dan intervensi dini pada anak autis, jurnal pendidikan anak, vol. III no 1 , bentul
Baktiningsih, Kurniati, 2009, program terapi anak autis di SLB negri SEMARANG, jurnal kependidikan, vol XXXIX, no2 universitas semarang

Indina, Gheista, Handajani, Rinawati P. , Laksmiwati, Triandi, Penerapan Warna Dan Cahaya Pada Interior Ruang Terapi Dasar Dengan Pendekatan Visual Anak Autis, jurnal arsitektur, Universitas Brawijaya,

hhtp//Autism,Sebuah Ganggua Perilaku Pada Anak_Jurnal Pediatri.htm di akses 25 okt 2017

hhtp:// Jenis Terapi Autis.htm diakses 02nov2017

hhtp://D: Jumlah Penderita Autis di Indonesia KLINIK AUTIS online.htm diakses 25 nov2017

marzuki, hendri, 2013, sekolah autis di pekanbaru, tugas akhir,program S1 jurusan teknik arsitektur pekanbaru, pekanba 